\title{
YMPÄRISTÖ TALOUSKRITIIKIN PERUSTANA NÄKÖKULMIEN MONINAISUUS
}

Yhteiskuntatieteet vakiintuivat ympäristötutkimuksen osaksi noin puoli vuosisataa sitten 1960- ja 1970-luvuilla; hyvin pian sen jälkeen, kun ympäristöongelmat olivat nousseet laajan yhteiskunnallisen huomion kohteiksi. Ensimmäisessä vaiheessa uusia tutkimusperinteitä syntyi vakiintuneiden tieteenalojen piiriin. Alojen nimityksiin lisättiin etuliite "ympäristö" - näin saatiin esimerkiksi ympäristösosiologia, ympäristötaloustiede, ympäristöhistoria, ympäristöpolitiikka, ympäristöetiikka, ympäristöoikeus ja niin edelleen.

Asetelma on sittemmin monipuolistunut ja monitieteistynyt. Ympäristön yhteiskunnallinen merkitys ei jäsenny enää perinteisten, joskus ahtaiden tieteenalakategorioiden mukaisesti. Asetelmaan ovat vaikuttaneet suuresti globaalit ongelmat, jotka leikkaavat yhteiskunnallisen toiminnan eri sektoreiden läpi. Ympäristöä koskevat ajankohtaiset tutkimusteemat märitellään nykyisin ongelmalähtöisesti. Tätä korostaa erityisesti ajatus antroposeenista, jonka mukaan maapallon nykyvaihe ilmentää uudenlaista geologista aikakautta, jota hallitsevat ihmisten aiheuttamat peruuttamattomat ympäristömuutokset.

Antroposeenin prisman läpi katsottuna mitä erilaisimmat ympäristöongelmat kietoutuvat toisiinsa. Niiden yhteinen nimittäjä on ihmiskunnan kokonaisvaikutus maapallon olosuhteisiin. Oma tutkimuksellinen ongelmansa on, miten tätä muutosta kyetään jäsentämään ja arvioimaan.

Kaiken moninaisuuden keskellä voisi tuntua luontevalta ajatella, että talous on ongelmia yhdistävä tekijä. Siis nimenomaan "reaalitalous": se mitä taloudellisen toiminnan erilaisissa piireissä todella tehdään ja miten luonnon ainekset liittyvät tuohon toimintaan. Asetelma ei kuitenkaan ole näin yksinkertainen. Sekä talous että ympäristö ovat kokonaisuudessaan suoran ja empiirisen havainnoinnin ulottumattomissa. On mahdotonta täsmällisesti sanoa, mitä talous tai ympäristö" kokonaisuudessaan" käsittää. Tämän vuoksi tarvitaan useita erilaisia teoreettisia jäsennyksiä ja niiden välistä vuoropuhelua.

Tästä toteamuksesta seuraa kuitenkin keskeinen ongelma: Mikä on taloutta ja ympäristöä koskevien teoreettisten katsomusten ja materiaalisen todellisuuden suhde? Voimmeko puhua taloudesta ilman teoreettisia sitoumuksia, jotka peittävät ainakin osan talouden materiaalisesta todellisuudesta näkymättömiin? On vaikea erottaa toisistaan talous sinänsä ja taloutta koskevat teoriat, ja siksi myös talouden suhde luontoon hämärtyy.

Joseph Schumpeter (1883-1950) tiivisti tämän suhteen lähes inhorealistisen suoraviivaisesti: "Tietyn tosiasian tärkeydellä ihmiskunnan hyvinvoinnille ja tuon tosiasian tärkeydellä talousteorian selityspyrkimyksille ei ole mitään suhdetta toisiinsa." (Schumpeter [1934] 1983, 11). Toteamuksensa hän perusteli talouden omalakisuudella. Schumpeter oli yksi 1900-luvun tarkkanäköisimmistä talousteoreetikoista, mutta ympäristön merkityksen suhteen hän oli sokea. Talousteoriat nimittäin useimmiten peittävät niiden luonnon elementtien materiaalisuuden, joihin talous itse asiassa perustuu. Taloustiede tarvitsee rinnalleen muiden tutkimusalojen apua, kun talouden ja ympäristön suhteita selvitetään.

Yhteiskunnallisen ympäristötutkimuksen asemaa selventää Arto Noron esittelemä kolmijakoinen jäsennys sosiologisen teorian lajityypeistä. Jäsennyksen ainesosat ovat yleinen 
teoria, aikalaisdiagnoosi ja tutkimusteoria. Yleisen teorian tasolla antroposeeni saattaa kaikki aiemmin yhteiskunnalliseen ympäristötutkimukseen kehitetyt yleiset käsitteet ja teoreettiset kehykset epäilyksenalaisiksi. Ei ole olemassa yleistä yhteiskunnallista teoriaa siitä, miten ympäristön muuttumisen aiheuttama umpikuja todella vaikuttaa yhteiskunnan rakenteisiin. Radikaalisti uuden piirteitä ei voi johtaa siitä, mitä oli aiemmin.

Toki on mahdollista oppia klassisten teoreetikoiden kuten Karl Marxin (1818-1883) tai Max Weberin (1864-1920) avulla tärkeitä seikkoja nyky-yhteiskuntien dynamiikasta. Eri yhteiskuntien välillä on kuitenkin valtavasti vaihtelua. On olennaisen epäselvää, miten eri puolilla maailmaa toteutuvat kehityskulut voitaisiin sovittaa yhteen yhtenäiseen kokonaisnäkemykseen. Ongelmat muuttavat jatkuvasti muotoaan kansainvälisten suhteiden myllerryksessä.

Voidaan myös ajatella, että ajatus antroposeenistä on aikalaisdiagnoosin tuorein ilmentymä. On hyvin ajankohtaista, että koko maapallon kattavat ympäristön muutokset asettavat ihmiskunnan elinehtojen jatkuvuuden kyseenalaiseksi. Esimerkiksi Ulrich Beckin (19442015) käsite riskiyhteiskunta, 1980-luvun aikalaisdiaganoosi, käsitti tavallaan samanlaisen idean. Näkemysten välillä on kuitenkin ero. Beckin riskiyhteiskunta oli ensisijaisesti metafora, joka paikantui sosiaalisiin suhteisiin. Antroposeeni on sen sijaan kiinnittynyt ihmiskunnan materiaalisen perustan muutokseen.

Paradoksaalisesti vaikuttaa siis siltä, että yhteiskuntien ja ympäristön suhteiden ongelmat laajenevat ja hajaantuvat samanaikaisesti. Tästä seuraa selkeä tehtävä: on tarpeen rikastuttaa tutkimusteorioita. Noron alkuperäisen luonnehdinnan mukaan tutkimusteoria perustuu käsitteelliseen kehittelyyn, joka puolestaan perustuu tutkimuksen välittömästi tuottamaan empiiriseen evidenssiin.

Uudenlaisessa tilanteessa tutkijan vaikein ongelma on muovata itselleen omaa tutkimuskysymystään vastaava tutkimusteoria. Tämä vaatii kehittelyä usealla tasolla. Tutkimusteorian tulee ensiksikin olla sopusoinnussa ongelman luonteen kanssa. Toiseksi on varmistettava, että teoria on sopusoinnussa yleisen yhteiskunnallisen näkemyksen kanssa. Tutkimusteorian kehitys voi käsittää monia aineksia, mutta se ei ole mielivaltaista. Ja lopuksi: tutkimusteorian tulee johtaa päätelmiin, jotka edistävät ongelman ratkaisemista tai vähintäänkin sen selkiytymistä.

Tämä Tiede \& Edistys -lehden teemanumero on omistettu ympäristöperustaiselle talouden ja talousteorian kritiikille. Tavoittelimme yksittäisten kirjoitusten osalta täsmällisyyttä ja kokonaisuuden osalta moninaisuutta. Tähän valikoimaan sisältyvät kirjoitukset lähestyvät aihepiiriä jokainen omasta näkökulmastaan ja käsitteellisistä ratkaisuistaan. Kokonaisuus ilmentää yhteiskunnallisen ympäristötutkimuksen monipuolisuutta nimenomaan tutkimusteorioiden tasolla. Toivomme, että tämän teemanumeron artikkelit monipuolistavat ja voimistavat entisestään suomeksi käytävää tieteellistä ja yhteiskunnallista keskustelua talouden kysymyksestä globaalin ekologisen kriisin ja antroposeenin aikakaudella.

TEEMANUMERON TOIMITTAJAT YRJÖ HAILA, MIKKO JAKONEN JA TERO TOIVANEN

VIITTEET

Schumpeter,Joseph ([1934] 1983) The Theory of Economic Development. An Inquiry into Profits, Capital, Credit, Interest, and the Business Cycle. Käännös Redvers Opie. New Brunswick, New Jersey: Transaction Books.

Noro, Arto (2000) "Aikalaisdiagnoosi sosiologisen teorian kolmantena lajityyppinä." Sosiologia 4/2000, 321-329. 